\title{
Proposing an agonistic analytical framework to assess participatory initiatives in Brazil
}

Natália Massaco Koga

Ministério do Desenvolvimento Social e Combate à Fome (MDS)

This article intends to review the main arguments developed by the contemporary literature dedicated to assess the conditions for and outcomes of social participation in Brazil. Considering the emerging criticism that new aspects should be incorporated to this debate, this work explores an alternative line of thinking - Chantal Mouffe's agonistic theory of democracy - from which I contend a new analytical framework can be developed in order to improve the understanding of the contributions of social participation to Brazil's democracy.

Keywords: state and society, social participation, democracy

\section{Proposta de uma abordagem analítica agonística para avaliação de iniciativas participativas no Brasil}

Este artigo tem como objetivo analisar os principais argumentos desenvolvidos pela literatura contemporânea dedicada a avaliar as condições e resultados da participação social no Brasil. Considerando a crítica crescente à necessidade de incorporação de novos aspectos a esse debate, este trabalho busca explorar uma linha alternativa de análise a teoria democrática agonística de Chantal Mouffe - a partir da qual este artigo defende que um novo ferramental analítico pode ser desenvolvido para aprimorar o entendimento acerca das contribuições da participação social para a democracia brasileira.

Palavras-chaves: estado e sociedade, participação social, democraci

[Artigo recebido em 11 de novembro de 2015. Aprovado em 5 de abril de 2016] 


\section{Propuesta de un enfoque analítico agonístico para evaluar las iniciativas de participación en Brasil}

Este artículo tiene la finalidad de analizar los principales argumentos que ha desarrollado la literatura contemporánea que se dedica a evaluar las condiciones y los resultados de la participación social en Brasil. Debido a la creciente crítica sobre la necesidad de incorporarle nuevos aspectos a ese debate, en este trabajo se investigará a fondo una línea alternativa de análisis - la teoría democrática agonística de Chantal Mouffe - a partir de la cual, según defiende este estudio, se debe desarrollar una nueva herramienta analítica que mejore la comprensión acerca de las contribuciones que la participación social le aporta a la democracia brasileña.

Palabras-claves: estado y sociedad, participación social, democracia 
The multiplication of participatory initiatives ${ }^{1}$ in the last three decades in Brazil has captured the attention of various scholars and a significant body of literature has been produced on their functioning and practical outcomes. While deadlocks and limitations are recorded, possibilities and potentialities are also identified particularly in transforming the interplays between state and civil society in the political arena.

This article intends to review the main arguments developed by the contemporary literature dedicated to assess the conditions for and outcomes of social participation. Considering the emerging criticism that new aspects should be incorporated to this debate, this work explores an alternative line of thinking - Chantal Mouffe's agonistic theory of democracy - from which I contend a new analytical framework can be developed in order to improve the understanding of the contributions of social participation to Brazil's democracy.

The initial part of the article will discuss the main aspects of what is being called the "normative perspective" of analysis and which came to be the more propagated one in the field. Secondly, it will point out arguments raised by another branch of literature which contends the importance of these participatory spaces to provoke transformations in the relational arena of democracy. To sum up, this work will propose an alternative analytical framework that could deal with this broader dimension.

\section{Participatory initiatives under a normative perspective: putting deliberation into practice}

To start with, it can be argued that most of the investigations into participatory initiatives in Brazil focus on their institutional design or on normative aspects such as legal and administrative competencies (CôRTES, 2009a; ABERS and KECK, 2008). In this sense, their main question interrogates these initiatives' success in putting

\footnotetext{
${ }^{1}$ This article uses de the concept of participatory initiatives as any social space of interaction between representatives from the state and civil society. They can be institutionalised or not. Regarding the multiplication of institutionalised spaces of participation, data produced by General-Secretariat of the Presidency shows that from 1941 to May 2010, 109 national conferences were held in 40 different fields, ranging from more traditional areas, such as health, social care and human rights, to new topics including the environment, promotion of racial equality and local productive arrangements. From 1941 to 1994 - prior to Cardoso's government - 22 national conferences were promoted and all were basically related to the health field. It is nevertheless worth noting that these earlier conferences had a technical and intergovernmental character, and thus did not include the extensive public participation advocated by the participatory literature (CôRTES et al., 2009). During Cardoso's two mandates, from 1995 to 2002, 19 national conferences were held. Health issues continued to be one of the main topics, though new areas such as social security, human rights and food security started to feature more frequently. Lula's administration witnessed diversification among the topics and a marked increase in the number of events held, with 68 national conferences taking place, most of them introducing different topics of debate. From 2003 to 2006, at the municipal, state or national levels, around 2 million people took part at some stage (SILVA, 2009).
} 
their deliberations into practice, that is to say, in making direct decisions and having a concrete influence over the future of public policies.

Different investigations in the field show a low level of satisfaction among participants with regard to participatory spaces' ability to get their proposals or decisions transformed into practical measures (SOUZA, 2008; SILVA, 2009).

A common starting point in these studies is to identify the sorts of results expected from participatory initiatives. They call attention to the fact that these spaces have different initial attributes and institutional mechanisms for guaranteeing their realisation. While some are created merely to produce proposals, others have been framed by legislation to take a clear decisional role. ${ }^{2}$ In this sense, some investigations suggest that the level of influence of a participatory initiative is directly correlated with its level of institutionalisation (SILVA, 2009).

Other key points commonly underscored by this line of interpretation are the composition and forms of representation in participatory mechanisms. Some authors argue that the determining factor in the level and quality of representativeness of these spaces is the procedure through which they define their participants (LüCHMANN, 2008).

Authors discuss the implications of common practices in public policy councils such as the exclusive application of the parity criterion ${ }^{3}$ for representation and little alternation between different civil society representatives - who are usually members of organisations representing the main sectors of society (MORONI, 2005; SOUZA, 2008; LÜCHMANN, 2008).

Comparing this indirect form of representation with the direct participation that takes place in participatory budgeting, Lüchmann (2008) suggests that while in the latter there is a greater capacity for inclusion and diversity, the former relies upon a false assumption of relative homogeneity in civil society. As stated by Souza (2008) this procedure leads to the convergence of viewpoints and political projects, inhibiting the representation of minority and conflicting positions.

Another related aspect is the uncertainty existing around the interests that should be represented by participants (GoHN, 2003; SOUZA, 2008). Should government representatives defend the interests of the government in power? Given that in several cases there is no uniform position within government, what interests should government participants be representing? Should representatives from civil society defend the interests of their organisations or give cognisance to the wider interests

\footnotetext{
2 This is the case, for instance, with the legal prescriptions regarding the precondition of holding national conferences in order to allocate resources in the federal budget in specific areas.

${ }^{3}$ That is basically the definition of an equal number of participants from each sector of society to take part of the participatory mechanism.
} 
of society? How does one assure that the voices of minority or non-organised members of society can be heard? (SOUZA, 2008; MORONI, 2005; ABERS and KECK, 2008). In other words, the debate which has grown up around these questions raises challenges to the traditional concepts of representation. Quoting from Lüchmann (2008), "participation does not substitute, but reconfigures representation" (p. 96, own translation).

Other investigations have advanced this debate, in arguing that legal prescriptions and institutional design do not always guarantee the implementation of the proposals and decisions made in participatory spaces (SILVA, 2009). Additional factors, such as the internal conditions pertaining in government and civil society, are equally essential in this sense.

Several investigations identify certain fragilities in both civil society and the state with regard to their ability to perform in participatory systems.

From the civil society perspective, two major concerns must be highlighted. Firstly, the examination of these participatory initiatives frequently shows that the representatives of civil society often have difficulties in keeping an effective channel of communication and engagement with their organisation's grassroots. In several cases, civil society organisations feel satisfied with the appointment of their representative, failing to monitor how the deliberations develop; failing to give support to their representatives; or to provide up-to-date information to their members (SILVA, 2009).

There is even evidence that the constitution of institutional spaces for participation is weakening the power of the informal and autonomous interactive forums formerly engaged in by civil society organisations (SOUZA, 2008). To keep these autonomous forums alive can be a crucial challenge to the sustainability of the participatory project, given their essential role in broadening the capillarity of participatory spaces as well as in shortening the distance between representatives and the organisations' grassroots (SouzA, 2008).

A second important condition that affects the quality of civil society participation relates to the level of technical knowledge necessary to discuss the subject under consideration (ABERS and KECK, 2008; SOUZA, 2008; OliVEIRA, 2005). Certain areas, such as budgetary deliberations or the implementation of particular public policies, demand specific knowledge and skills from participants. Investigations which recognise complexity as a challenge to broader participation, also argue that "it does not represent a limit a priori if there is a disposition to supply the necessary conditions for participation, such as access to relevant and adequate information, in a form compatible with the profile of those interested in participating" (SOUZA, 2008, p. 51, own translation). 
From the state perspective, investigations show a significant unpreparedness on the part of government to function under a participatory logic.

Silva (2009) points out, for instance, the internal operational problems that government tends to find in transforming the deliberations made at national conferences into practical measures. Conflicts between the dynamics of participatory spaces and state's traditional bureaucratic procedures are identified as among the main hindrances to the efficiency of deliberative initiatives. The same can be said about the difficulties in promoting horizontal coordination within the state, especially in cases in which the deliberation deals with transversal issues which demand multiple actions from different agencies (SILVA, 2009; SOUZA, 2008). In spite of the fact that some improvement has been made in this area, such as the promotion of joint conferences to debate common topics that involve different ministries, unsuccessful instances still arise. Examples include those conferences created to discuss related subjects but which do fail to communicate among themselves ${ }^{4}$ or joint measures which meet with impediments due to the lack of an adequate administrative structure and resources (SILVA, 2009; SoUZA, 2008). Quoting from Souza (2008), "there is no effectiveness when the decision process is built around a public policy that does not exist or will not exist due to the lack of structure of the state itself" (p.53, own translation).

The problem of coordination is aggravated when other forums come to be involved, such as the legislative power. Frequently, the deliberations reached in national participatory spaces demand modifications to the federal legislation which would need to be negotiated with the national congress in order to be put into practice. In other words, in many cases intense coordination between participatory and representative bodies is required. ${ }^{5}$

Improvements must be made to all these areas. Otherwise, there is a high risk of diminishing the relevance of participatory spaces due, for instance, to the cooptation of less organised groups or to the creation of alternative spaces of influence by dominant sectors.

\footnotetext{
${ }^{4}$ There are some cases in which the nature of the issue is inherently complex and can be examined from different perspectives. It can be illustrated, for example, by the difficulties in articulating the conflicting results achieved through the "Conference of Cities", which discussed policies for making improvements in urban spaces, and the "Conference of Environment", which deliberated the issue of expanding preservation areas in urban spaces (SILVA, 2009).

${ }^{5}$ Despite the challenges of coordination and negotiation mentioned in this paragraph, recent research shows some improvements in the interaction between the outcomes from the representative and participatory realms. Pogrebinschi et al. (2010), for instance, show new evidence that propositions originating in the national conferences are exerting increasing influence on the debating agenda of the Brazilian National Congress.
} 
Indeed, some studies, including that coordinated by Santos and Avritzer (2005), identify different cases in which participatory spaces turn out to have transformed the proposed inclusion into exclusion, and the supposed participation into submission. According to the authors, these situations were provoked by several factors, such as the resistance put up by conservative forces and the contrast between the modes of functioning found in participatory initiatives and the traditional forms of politics.

In conclusion, I would propose that the debate as so far depicted begins to point to a new trend of analysis. Rules of functioning and institutional design need to be understood in order to frame an initial view of the limits and potentialities of participation. By the same token, the analysis of internal conditions can make a contribution that advances this analysis. However, more recent investigations have indicated that additional aspects must be taken into consideration in order to build a comprehensive understanding of the achievements gained through participatory initiatives, as well as a picture of their impacts on the democratic system. These aspects include a consideration of external conditions and the broader contexts within which the state and civil society are embedded and function.

\section{New patterns of relationship between state and civil society and emerging shifts in the comprehension of the democratic impacts}

In the more recent literature on participation, a number of authors observe the inadequacy of assessing the democratic outcomes of participatory initiatives through the traditional analytic categories. They argue that a strictly normative and institutional analytic approach fails to capture what is probably the most relevant field of transformation promoted by participatory initiatives, that is, the shifts in the patterns of relationship between state and civil society (ABERS and KECK, 2008; CÔRTES, 2009).

On the one hand, the results of participatory initiatives may be considered unsatisfactory when subjected to the sort of analysis that looks exclusively at efficiency in the management of public policies. As set out above, the examination of practical instances demonstrates that the goal of improving public policies does not depend only on participatory mechanisms. Rather, it also demands the prevalence of particular internal conditions within the state and civil society that do not automatically accompany the institutionalisation of participatory spaces. On the other hand, investigations also indicate that the conclusions may be different from the point of view of the capacity for participation to promote changes in the country's political culture. 
Recent studies offer evidence for the potential of participatory initiatives to stimulate transformative social interaction within civil society and also between actors from the state and civil society (CHAGAS et al., 2003; SOUZA, 2008; SILVA et al., 2009).

As argued by Barth (2006), in cases where a favourable environment gives mutual recognition to these actors as legitimate parts of the process, this can result in

[...] increasing awareness and pressure for more transparency and accountability of public actions, an improved qualification of civil society to discuss policy issues, more public control and denunciation of misuse or corruption as well as changing attitudes of public sector managers towards the importance of peoples' knowledge and contribution. (p. 262).

Carvalho (1997), in his investigation of the National Council for Health, goes further, suggesting that public policy councils should be envisioned as more than institutionalised spaces for exercising social control. Additionally, there should be recognition of their potential for constituting a space in which, by means of confrontation between different projects, new public actors are formed and public interest is socially constructed and identified (CARVALHO, 1997; GOHN, 2003).

Following this same line of thinking, Abers and Keck (2008) point out the potential of participatory mechanisms to produce what the authors call "fertile relationships". The authors explore two assumptions of the radical pluralism perspective on democracy. The first is the idea that political democracy is constituted by practical actions rather than by arguments alone. The second relates to the essential role of conflict. In relation to this latter assumption, Abers and Keck (2008) suggest an additional element for interpreting the importance of conflict by arguing that it is also crucial for the emergence of innovation. Accordingly, innovation is not a product of:

[...] aggregation or negotiation of pre-existing ideas, but of a sort of a creative combustion that produces ideas that would never exist in another way. [...] The catalyst element is more than the interaction among ideas and motives: it sprouts from the establishment of concrete relations between actors who develop the capacity to use resources in a brand new form. The interaction affects not only their understandings, but also what individuals do; it transforms the actors' capacity to influence in social life (ABERS and KECK, 2008, p. 108, own translation).

In order to capture the transformative interactional elements introduced above, authors such as Moura and Silva (2008) and Tatagiba (2004) emphasise the importance of observing shifts that take place in social relations and social trajectories.

In order to do that, it is contended that one should start from the assumption that neither participatory mechanisms, nor civil society participation are, as some 
works suggest, inherently democratic; but equally, neither are they in essence a reproductive mechanism of domination and inequality. It accepts that any result may be possible, placing its emphasis on analysing the conditions that lead to the result (SILVA, 2007).

Additionally, as noted by Tatagiba (2004), an analysis which takes into account the relational aspects of initiatives such as public policy councils can contribute to understanding "how actors from civil society combine and articulate their different fronts of action and how they value participation in spaces such as the councils" (p.210, own translation). In other words, the author establishes how networks that include actors from civil society and the executive or legislative powers are relevant to the way actions are defined and the level of influence of civil society organisations. As Tatagiba (2004) suggests, previously constituted networks can affect the results and relevance of these participatory spaces.

I argue that the discussion of further conditions for participations brought into the foreground by this collection of new proposals is constituted within a broader understanding of participation as a means of radicalising democracy. In view of that, the tenets of the theories of radical democracy should be more explored to give additional elements in order to assess the participation outcomes. With this goal in mind, I argue that Chantal Mouffe's theory of agonism can contribute analytical tools that are appropriate for this exploration, and the reasons for this will now be set out.

\section{The participatory project from an agonistic perspective}

Mouffe's agonistic theory is posited in opposition to the view of democracy in terms of a set of impartial procedures and envisages a concept of pluralist democracy which recognises the constitutive aspect of conflict and antagonism in the political realm (Mouffe, 2005a).

Mouffe (2009) argues for an anti-essentialist understanding of pluralism, thus rejecting the idea of things as pre-formed entities and questioning the unanimity and homogeneity assumed in strands of liberal thinking. The author claims that to ignore or to underplay the relevance of differences is in fact the way to negate plurality and to justify exclusion.

Therefore, instead of looking for procedures that eliminate antagonism and reduce pluralism, the agonistic theory recognises not only the constitutive but also the positive role of differences in modern democracy (MoufFE, 2009). Drawing from what Henry Staten describes with reference to Derrida's work as the 'constitutive outside', Mouffe (2009) begins from the argument that the formation of any social objectivity takes place in a context of power relations and is thus essentially political. 
In this sense, difference and exclusion are fundamental to the constitutive dynamic of a social objectivity. Hence, the construction of collective identities, which agonistic theory argues to be fundamental to democratic politics, finds its basis in a process of discrimination in which a we is constituted through differentiation with a they (Mouffe, 2005a).

Mouffe's agonistic mode of democracy challenges the deliberative model's emphasis on rational consensus. Conversely, it recognises the conflictual character of the modern pluralist society and the impossibility of reaching a wholly rational solution within it (MoufFE, 2009). The agonistic theory calls attention to the risks of not acknowledging antagonisms and confrontations, which can potentially result in alienation and apathy about political participation. It argues that the impossibility of formulating conflict in political terms tends to favour essentialist forms of identification around issues such as religion, nationalism and ethnicity (MoufFe, 2005a).

Mouffe (2005a) argues instead for a "conflictual consensus". She asserts that "consensus is needed on the institutions constitutive of democracy and on the 'ethico-political' values informing the political association - liberty and equality for all but there will always be disagreement concerning their meaning and the way they should be implemented" (p. 31). According to her formulation, this disagreement would in fact be the basis for maintaining a vibrant democracy (MoufFe, 2005a).

Acknowledging the essential character of difference in a pluralist society and the impossibility of eradicating power and conflict, the agonistic theory contends that an important task of democracy is to pursue the 'taming' of antagonism in the direction of an alternative type of relation, which is referred to by Mouffe (2005b) as agonism.

In an agonistic relation there is a mutual recognition of the legitimacy of the parties in conflict. They identify each other as 'adversaries' - instead of 'enemies' - that share a common symbolic terrain in which conflict can take place. Thus "conflictual consensus" - agreement on the ethico-political principles that inform the political association but disagreement about the interpretation of these principles - can exist between them. (Mouffe, 2005a; 2010).

Mouffe (2005a) underscores that this concept of 'adversary' is distinct from the liberal notion of competitors playing in a neutral field. It does not make the assumption that either negotiation or deliberation can reconcile distinct interests. The author argues otherwise that:

While antagonism is a we/they relation in which the two sides are enemies who do not share any common ground, agonism is a we/they relation where the conflicting parties, although acknowledging that there is no rational solution to their conflict, nevertheless recognize the legitimacy of 
their opponents. [...] This means that, while in conflict, they see themselves as belonging to the same political association, as sharing a common symbolic space within which the conflict takes place. (Mouffe, 2005a, p.20).

Accordingly, the legitimisation of the adversary in terms of mutual general political grounds and the identification of the place of conflict in a "common symbolic space" provide the basis for an agonistic relation.

For Mouffe (2005a), the agonistic struggle can diffuse the emergence of antagonistic conflicts, given its potential for allowing dissenting voices to be heard and for opposing alternatives to emerge. As a consequence, it can be argued that the agonistic struggle allows power relations to be questioned and, ultimately, for the dominant hegemony to be challenged.

Mouffe (2005a) does not reject the possibility of compromises, although she understands them as manifestations of momentary intervals within an intermittent process of confrontation. Given that every consensus is a political product and expresses a 'provisional hegemony' - a 'stabilisation of power' - consensus should never be represented as a final reconciliation. Instead, it should always be subjected to contestation (Mouffe, 2005; 2009).

To conclude, it is worth emphasising a final issue raised by agonistic theory. That is the relevance of exploring what sorts of institution - understood in a 'very wide sense $^{6}$ - can contribute to allowing conflict to be expressed in an adversarial form, as well as building up 'a vibrant agonistic public sphere of contestation'. As Mouffe (2005a) puts it:

Instead of trying to design the institutions which, through supposedly 'impartial' procedures, would reconcile all conflicting interests and values, the task for democratic theorists and politicians should be to envisage the creation of a vibrant 'agonistic' public sphere of contestation where different hegemonic political projects can be confronted. This is, in my view, the sine qua non for an effective exercise of democracy. (p. 3).

This provocation can be used in the Brazilian context in order to question, for instance: what sort of institutions could favour the creation of agonistic public spheres? Do the participatory spaces emerging in Brazil contribute to this process? Can these initiatives be seen as the kind of institution which plays the role of constituting alternative agonistic spheres? What sort of features or conditions could facilitate or inhibit this role?

\footnotetext{
${ }^{6}$ In her interview for Miessen (2010), Mouffe explains, "I use 'institution' in a very wide sense - in terms of an ensemble of practices, language games, discourse. But also traditional institutions as parties, as well as other political institutions as different forms of participation of a diversity of people at local and other levels" (p. 110).
} 


\section{What kinds of institution and mode of participation might foster the radicalisation of democracy?}

Initially, it is worth noting that over the last decade, the term 'participation', similarly to the term 'civil society' in the 1980s, came to be applied as a fashionable buzzword across different areas of knowledge and forms of discourse. In the political field, for instance, it can be easily identified in both the more radical and the more conservative discourses. Hence, the examination of any specific practice demands a prior clarification of the meanings and intentions which uphold the term by which it is denoted.

The use of the idea of participation by contrasting events such as the World Social Forum and the Davos Forum is underlined by Mouffe (2010) as arguing for the need to distinguish what is entailed in each discourse and practice that adopts this term.

The scholar raises a critique ${ }^{7}$ of what she categorises as a form of participation which reinforces conditions of exploitation by making individuals take part and getting them to accept a given consensus. As stated by Mouffe (2010), this in fact constitutes an example of what is referred by Gramsci as a 'passive revolution', meaning the strategy of "neutralizing the demands that could be subversive to an existing hegemonic order by satisfying them in a way that undermines their subversive potential" (p. 134).

In contrast, Mouffe (2010) supports forms of what she calls an 'agonistic mode of participation', which is conceived as a radical approach through a form of intervention that allows people the possibility of real choice, enhancing the subversive potential of disturbing consensus and challenging hegemony.

It is worth emphasising that this article is interested in raising elements to assess the dynamics and conditions conducive to this latter kind of participation, agonistic participation.

To start with, it will be useful to set out Mouffe's (2010) arguments for the possibility of choice in a condition where different positions can be confronted. I will now explore the contention that this should be considered one of the essential elements for an agonistic mode of participation.

\footnotetext{
${ }^{7}$ Other scholars express different criticisms against particular forms of applying participation. Miessen (2010) points out the problems of what he calls "outsourcing responsibility", which can be outlined as the process adopted by a "ruling majority" - for example, a government or politicians - to shift their own responsibility for making decisions onto external entities, such as participatory structures created to make people believe that they are taking part of the political process. Authors such as Korf (2010) and Stratford et al. (2003), in their turn, call attention to the implications of displacing the participatory debate towards the moral realm in ideas of development, responsible citizens and communities.
} 
As asserted by the author (Mouffe, 2010):

Thinking of participation along these lines will always require the choice between different alternatives. So you participate, but for you to do so, you need to have the possibility of choosing, and not simply participating in the creation of a consensus. It's necessary to have an alternative that implies a decision between alternatives that can never be reconciled. [...] If you have opposing alternatives, you participate in the decision about which alternative should be adopted. It means that there will be some alternatives that will not be adopted, which will in fact be negated. (p. 127).

Therefore, in an agonistic participation, the act of choice is not merely notional. It is rather a judgment between genuine alternatives. There must be always the possibility of choosing between irreconcilable alternatives. This implies that, in this mode of participation, participants accept that in order to get the chosen alternatives adopted, the opposing alternatives have to be negated (MoufFE, 2010).

However, it needs to be recognised that acceptance of this kind can only occur if participants are confident that confrontation between the alternatives has taken place and that the result will never be a final decisive one.

That is to say that acts of choice, and consequently of exclusion, must be preceded by a confrontation between real alternatives. This must be a confrontation in agonistic terms, thus involving adversaries to be convinced or defeated, rather than enemies to be destroyed.

This formulation thus acknowledges agonistic tenets regarding the impossibility of ultimate closure in the agonistic struggle, as well as the arguments raised through empirical work concerned with the representation of the minority and conflicting voices.

To sum up, it suggests that to keep an agonistic space alive, participants need to share the perception that participation is an unending process, because within such a forum, there is a place for different alternatives to be manifested and contrasted, as well as there being no final decision by which any of them will definitively be eliminated. Therefore, it is necessary to conceive a decision as an open process which allows other alternatives to be contemplated throughout time.

I suggest though that the perennial possibility of choice between real alternatives in contest is not in itself sufficient to foster participatory institutions that can contribute to the construction of agonistic public spheres. Integrating Mouffe's (2005a) formulation on the concept of 'adversaries', it should be recognised as equally necessary that participants consider themselves as sharing "a common symbolic space within which the conflict takes place" (p.20). In this regard, it can be stated that from this agonistic perspective, participants can envision that being in conflict in this sort of forum means that they share with their adversaries 
a symbolic space underpinned by the same 'political association'. Again, it is the general understanding about having a place where opposition and conflict can be made explicit that can draw people around this symbolic space. It is what Mouffe (2005b) highlights as the integrative role of conflict.

The process of constituting different alternatives is also a crucial point in this discussion of the conditions for an agonistic mode of participation. From the agonistic literature, it may be concluded that alternatives are generated from the existence of different political identities, which carry competing demands and hegemonic projects. Accordingly, I suggest that the possibility for diverse and opposing collective political identities to emerge should also be seen as vital for nurturing agonism in participatory spaces.

At this point, it is worth rescuing three relevant aspects related to agonistic theory's concept of collective political identities. The first consists in recognising that their construction is in fact the result of processes of discrimination between a 'we' and a 'they'. The second involves the relevance of passion in this process. Acknowledging phenomena such as mass political movements and nationalism, Mouffe (2005a) illuminates how collective identification demands the mobilisation of the affective dimension. Finally, the third aspect relies on the agonistic antiessentialist premise that leads to a concept of political identities which, rather than being pre-defined or immutable entities, are instead understood as undergoing constant shaping and reshaping in the public sphere (LACLAU and MoufFE, 2001).

This leads to the question of what sort of conditions participatory spaces should foster in order to facilitate the emergence of political identities and contests between them, understanding these processes in agonistic terms - in other words, comprising elements of transitoriness, mobilisation of passion and the we/they discrimination described above.

I suggest that White's (2010) work on the conception of "common" in the European context can contribute reflections relevant to this question. Looking for what would be the necessary elements for legitimising a European polity, White (2010) challenges the existing formulations ${ }^{8}$ which he claims are depoliticising.

\footnotetext{
${ }^{8}$ White (2010) distinguishes three main lines of thinking dedicated to exploring the "European common": maximalist, minimalist, and a strand focused on the idea of shared values and principles. As formulated by the author: "The conclusion one may take from examining proposals to conceive the European common in terms of shared values and principles complements those arrived at previously. No conceptualisation of the collective bond is of such descriptive plausibility that it must be accepted at face value: the political implications of each are an appropriate element in their assessment. By demanding a high degree of regularity and consensus across the citizen body, rather like a cultural bond, a thick values bond is likely to downgrade the importance of political adversarialism in the life of the political community. Alternatively a formulation in minimalist terms, where that which is shared is universal, is depoliticising in a different way, since it may weaken attachments to the polity and since - like a security or a commercial bond, though by dissimilar reasoning - it may empty public life of the pursuit of all but the most general shared ends." (p.112).
} 
In their place, White (2010) proposes the idea of a collective bond that takes into consideration conflict and the political dimension.

Finding inspiration in Mouffe's arguments, White (2010) conceives two main features in his concept of a 'political bond', which are the 'emphasis on adversarialism' and the 'emphasis on substantive problems'.

The 'emphasis on adversarialism' discusses the condition whereby the citizen body has a common sense of sharing the basic tenets of democracy, but at the same time admits of disagreements over their meanings. In this context, where opposing views and objectives can be contested, citizens participate as a way of making their voices heard and defending their positions. In this sense, the 'emphasis on adversarialism' deals with similar concerns raised by the aspect already discussed of 'sharing a common symbolic space within which the conflict takes place'.

Notwithstanding these arguments, I would contend that this formulation could be put in a rather different way when assessing its applicability to this discussion on the conditions for an agonistic participation. It could incorporate two additional elements related to the idea of conflict which are highlighted in empirical studies including those of Abers and Keck (2008), Tatagiba (2004) and Stratford et al. (2003). These authors have shown that recognising the productive potential of conflict and making power relations explicit are essential factors for enabling what Stratford et al. (2003) refer to as a "relational space of dissent". I contend that to the idea of emphasis on adversarialism these two elements could be added when investigating participatory initiatives. Firstly, participants should not only recognise but should also make a collective effort to keep in motion the productive role played by conflict. Secondly, participatory spaces should enable the exposition and understanding of power relations and their dynamics. This is a crucial element for helping participants to understand the effects of previously established relations and trajectories, as well as learning how they can be transformed.

The 'emphasis on substantive problems', in turn, works with the idea of engaging citizens in the political decision-making process through adopting a problemoriented approach. This view suggests that a focus on substantive problems allows citizens to connect the decision making process with their everyday lives, making their participation in the political community more meaningful to them.

This work proposes that it is possible to take the use of these ideas further if one explores them in conjunction with the formulations of Marres (2005) on the role of issue formation and public involvement.

Marres (2005) begins her analysis from a noted debate in political theory between two North-American pragmatist thinkers of the 1920s, John Dewey and 
Walter Lippmann. ${ }^{9}$ Marres (2005) claims that both authors envisioned an essential role for issue formation in the process of public involvement. In short, they contend that public involvement takes place when the existing institutions fail to deal with an issue. In that situation actors who are affected by it "become involved in politics in order to compel institutions to provide a settlement for these issues" (p.165). As highlighted by Marres (2005), this argument contains the idea that, rather than threatening democracy, the complexity of issues in the industrial society in fact enables public involvement.

Starting from this point, Marres (2005) proposes some important developments. For the purpose of this article, two of these should be emphasised. Firstly, there is the reformulation of Dewey's concept of "issues as problems that actors are commonly implicated in" (MARRES, 2005, p.168). Based on empirical work, ${ }^{10}$ Marres (2005) claims that issues not only implicate individuals who are in cooperation but also involve actors in opposition who defend stands that can challenge and threaten one another. Secondly, the author raises criticisms of the reductionist view of democracy as a "problem-solving mechanism", arguing instead for an understanding of democratic politics where issues are conceived as enablers of the organisation of publics and thus of their own transformation of democratic spaces (MARRES, 2005). In other words, the settlement of issues is not an end in itself and does not mean the mere solution of specific common problems. It consists, instead, of a longer and fuller process of involving and organising publics, that allows the contestation of even the very place and type of arrangement where controversy and the articulation of issues will be expressed.

White's (2010) and Marres' (2005) formulations suggest the proposal of one additional condition to be examined in the case studies. It will be referred as

\footnotetext{
${ }^{9}$ Quoting from Marres (2007), "[t]o begin with, it should be emphasized that the Lippmann-Dewey debate is not generally considered to be about the role of issues in the enactment of public involvement. More often, it is viewed as a conflict between two normative positions on the possibility of democracy in technological societies: Lippmann's sober democratic realism versus Dewey's ideals of participatory democracy (RYAN, 1995; FESTENSTEIN, 1997). According to the standard view, Lippmann favoured a strong role for expert advice in government decision-making, with limited input from citizens. He was a 'disappointed idealist', who claimed that political affairs in the industrial world had become so complex that ordinary citizens could not perform the governing role that democratic theory grants them. This disillusioned argument contrasts sharply with Dewey's claim that technological societies require more public involvement in politics, not less (PUTNAM, 2004). Dewey not only argued that it is possible to develop procedures that would enable citizens to contribute pertinent opinions to debates about the complex public affairs that are characteristic of industrialized societies. He also claimed that intelligent decision-making will occur only when expert knowledge-making is matched by citizen participation in public debates. The Lippmann-Dewey debate, therefore, is often portrayed as a contest between an advocate of expertocracy and a proponent of participatory democracy" (p. 766).

${ }^{10}$ The empirical investigation was on the insertion of the issue of climate change into the Extractive Industries Review (EIR) controversy on the Web.
} 
the possibility of issue formation. This relates to the potential of participatory initiatives to function as realms for public involvement in disputes around the settlement of issues, meaning the process of individuals' engagement around issues connected to their lives and which are in dispute and are not necessarily being dealt with by the existing institutions. In this sense, participatory space would work as the forum in which these issues could emerge and be articulated in order to reach the public agenda.

White's (2010) conception of a political bond considers that "If opponents are constructed in relation to problems, and there is a plurality of problem 'domains', then there will be a plurality of we-they formulations rather than a single axis of confrontation" (p. 113). Hence, different constitutions of we-they will take place, given that every problem - and I would argue every issue as well - involves its own arrangement of adversaries. Through this dynamic, it could be argued, room for violent antagonism and absolute exclusion can be minimised in favour of the emergence of a plurality of identities and interconnected ties.

Mouffe $(2005 a, 2005 b)$ may be said to be arguing is in this same direction when she points out that political unity does not need to take place in a particular space or at a particular level. On the contrary, she recognises that the political dimension is localised in any geographical space or social relation. Therefore, she argues for the coexistence and interaction of initiatives at multiple levels and scales where democratic identification can be fostered and agonistic struggle can be performed. Some studies of participatory initiatives have begun to indicate the importance of enabling the emergence of, as well as articulation between, different fronts of action (TATAGIBA, 2004; MULLER, 2010). This articulation is not only essential for spreading and enhancing their power of influence but also for rendering their outcomes more coherent and effective. I propose that this can also be seen as a constitutive element for an agonistic form of participation.

One final point must be made regarding White's (2010) proposal. He calls attention to the essential role that the citizens' will and political movements play in forming a political bond. As stated by the author:

[...] a political bond will not be achieved solely through institutional design. Institutions can promote but they cannot themselves establish the sense of the common which may be the condition of their viability. [...] It is citizens themselves who must lead other citizens in furthering a political bond. This is likely to depend upon political movements 'from below' being able to engage people with a stronger sense of the comparable experiences of citizens in other EU countries, and with new ideas about what can be achieved through collective action. It is a question of remaking the common sense, and depends upon political will" (p.119). 
This qualification can find connections with Mouffe's arguments about the role of the affective dimension in the constitution of political identities. It also touches the concerns emerging from the empirical literature regarding the necessity of maintaining channels of communication and engagement between the participants and the grassroots level of their organisations. I would argue that civil society involving social movements and grassroots organisations - has an essential role in keeping alive an agonistic mode of operation as well as the cycle of identity constitution and reconstitution within a participatory space. Moreover, a critical role for participatory spaces would be to enable the relationship between civil society and the state to be configured in a political-conflictual mode.

\section{Final considerations}

This work aimed to contribute to the debate on the relevance of participatory instances in transforming the relationship between state and civil society, as well as the debate on possible links between participation and radical democracy. The following analytical framework is thus a proposal to identify relevant elements for these debates from practical cases. In other words, to identify shifts in the interplays between state and civil society and the conditions for an agonistic mode of participation that fosters the radicalisation of democracy.

In sum, I argue that besides the aspects commonly discussed by the more normative branch of the literature, mentioned in the beginning of this article, the elements proposed in the last section could be further explored in order to expand our understanding on the impacts of participatory experiences in Brazil's democracy. Accordingly, some of the questions that I suggest to be posed to the participatory experiences - which include not only the increasing number of formally constituted instances such as the conferences or councils of public policies, but also the recent public demonstrations such as the "Jornadas de Junho" - would be: Do these participatory initiatives allow the manifestation of different and opposing alternatives as well as their confrontation in an agonistic fashion? Are they functioning at some level as a common symbolic space where participants can express divergence and opposition? Is it possible to perceive the emergence of different political identities in these participatory spaces? Do these participatory initiatives function as spaces for public involvement around the settlement of issues? Do the participants of these initiatives recognise the productive and integrative role of conflict? What are the connections between the studied participatory experience and other forms and levels of agonistic struggle? Could one say that there is a coexistence of multiple and intertwined institutions within their fields? Ultimately, are these mechanisms contributing to the transformation of the relationship between state and civil society in Brazil in the direction of a more political-conflictual mode? 


\section{References}

ABERS, R. AND KECK, M. Representando a diversidade: Estado, sociedade e "relacões fecundas" nos conselhos gestores. Caderno CRH. 21 (52), p. 99-112, 2008. Available from: <http://www.cadernocrh.ufba.br/printarticle.php?id=549\&layout=ps>. Accessed on: 29 September 2009.

BARTH, J. Public policy management councils in Brazil: how far dos institutionalised participation reach? Public Administration and Development. 26, 253-263, 2006.

CARvalho, A. I. Conselhos de saúde, responsabilidade pública e cidadania: a reforma sanitária como reforma do Estado. In: Fleury, S. (ed.). Saúde e democracia: a luta do CEBES. São Paulo: Lemos Editorial, 1997.

CHAGAS, A. M. R. et al. A política de assistência e participação social: o caso do Conselho Nacional de Assistência Social. Texto de Discussão n. 1005. Brasília: IPEA, 2003.

CôRTES, S. V. Participação e saúde no Brasil. Rio de Janeiro: Editora FioCruz, 2009a.

S. V., et al. Conselho Nacional de Saúde: histórico, papel institucional e atores estatais e societais. In: Côrtes, S. V. (ed). Participação e saúde no Brasil. Rio de Janeiro: Editora FioCruz, 2009b.

FLEURY, S. Socialismo e democracia: o lugar do sujeito. In: Fleury, S. and Lobato, L., Participação, Democracia e Saúde. Rio de Janeiro: CEBES, 2010.

GoHn, M. G. Conselhos gestores e participação sociopolítica. São Paulo: Cortez, 2003. LACLAU, E. and Mouffe, C. Hegemony and socialist strategy: towards a radical democratic politics. $2^{\text {nd }}$ ed. London: Verso, 2001.

LÜCHMANN, L. H. H. Participação e representação nos conselhos gestores e no orçamento participativo. Cad. CRH. 21 (52), p. 87-97, 2008. Available from: <http:// www.scielo.br/scielo.php?script=sci_arttext\&pid=S0103-49792008000100007\&In g=en\&nrm=iso>. ISSN 0103-4979. doi: 10.1590/S0103-49792008000100007>. Accessed on: 3 March 2010.MARRES, N. S. No issue, no public: democratic deficits after the displacement of politics. Amsterdam: University of Amsterdam (Thesis for the degree of Doctor of Philosophy), 2005.

The Issues Deserve More Credit : Pragmatist Contributions to the Study of Public Involvement in Controversy. Social Studies of Science. 2007 (37), p. 759-780, 2007. Available from: $<$ http://sss.sagepub.com/content/37/5/759 $>$. Accessed on: 16 February 2011.

MIESSEN, M. The nightmare of participation: crossbench praxis as a mode of criticality. Berlin: Sternberg Press, 2010.

Moroni, J. A. Participamos, e daí? in Observatório da Cidadania - Textos para Debate, 2005. Available from: www.ibase.br/pubibase/media/ Participacao Moroni.pdf. Accessed on: 01/03/2010.

Mouffe, C. On the political. New York: Routledge, 2005a.

For an agonistic public sphere. In: Tønder, L. and Thomassen, L., Radical democracy: politics between abundance and lack. Manchester: Manchester University Press, 2005b. 
The Democratic Paradox. London: Verso, 2009.

Democracy Revisited: in conversation with Chantal Mouffe. In Miessen, M., The nightmare of participation: crossbench praxis as a mode of criticality. Berlin: Sternberg Press, 2010.

MourA, J. and Silva, M. K. Atores sociais em espaços de ampliação da democracia: as redes sociais em perspectiva. Revista de Sociologia Política, 16 (número suplementar), p. 43-54, 2008. Available from: <http://www.scielo.br/pdf/rsocp/ v16s0/a04v16s0.pdf>. Accessed on: 7 December 2009.

MULLER, J. A relação entre democracia, descentralização e políticas de saúde no Brasil: atualização do debate e estudo de caso em uma perspectiva comunicativa. Rio de Janeiro: Escola Nacional de Saúde Pública Sérgio Arouca. Fundação Oswaldo Cruz (Thesis for the degree of Doctor of Philosophy), 2010.

OliveIRA, M. S. C. Por uma construção democrática do direito à saúde: a Constituição Federal, os instrumentos de participação social e a experiência do Conselho Nacional de Saúde. Brasília: Universidade de Brasília (Dissertation for the degree of Master of Philosophy), 2005.

PogrebinschI, T. et al. Conferências Nacionais, Participacão Social e Processo Legislativo. Série Pensando o Direito, 27. Brasília: Secretaria de Assuntos Legislativos do Ministério da Justica, 2010.

SANTOS, B. and Avritzer, L. Opening up the canon of democracy. In: Santos, B., (ed.). Democratizing democracy. New York: Verso, 2005.

Sılva, M. K. et al. A dinâmica das relações sociais no Conselho Nacional de Saúde. In: Cortes, S. V. (ed.). Participação e saúde no Brasil. Rio de Janeiro: Editora Fiocruz, 2009.

SILVA, E. R. A. Participação social e as conferências nacionais de políticas públicas: reflexões sobre os avanços e desafios no período de 2003-2006. Rio de Janeiro: IPEA, 2009. Available from: <http://www.ipea.gov.br/sites/000/2/publicacoes/tds/ td 1378.pdf> Accessed on: 28 February 2010.

SouzA, C. H. L. Partilha de poder decisório em processos participativos nacionais. Brasília: Universidade de Brasília (Thesis for the degree of Doctor of Philosophy), 2008.

STRATFORD, E. et al. Relational spaces and the geopolitics of community participation in two Tasmanian local governments: a case for agonistic pluralism? Transactions of the Institute of British Geographers. New Series. 28, p. 461-472, 2003. Available from: http://www.jstor.org/stable/3804392. Accessed on: 07 December 2010.

TATAGIBA, L. Conselhos gestores de políticas públicas e democracia participativa. Revista Sociologia Política. 25, p. 209-213, 2004.

White, J., (2010). Europe and the Common. Political Studies. 58, 104-122.

Natália Massaco Koga

Doutora em Ciência Política pela University of Westminster, Londres - Reino Unido, Mestre em Administração Pública Fundação Getúlio Vargas (Eaesp/FGV), Bacharel em Direito pela Universidade de São Paulo (USP) e Especialista em Políticas Públicas e Gestão Governamental. Contato: nmkoga@yahoo.com.br. 